\title{
The Effect of Plyometric Training towards Long Jump of Squat Style Ability on Second Grade Male Students in SMP Negeri 2 Manganitu
}

\author{
Fredrik Alfrets Makadada ${ }^{1}$, Djajaty Mariana Lolowang ${ }^{2}$ \\ ${ }^{1,2}$ Faculty of Sports Science, Universitas Negeri Manado, Indonesia \\ alfretsfm@yahoo.com
}

\begin{abstract}
The aims of the study to find out the extent of the effect of plyometric training on the ability to squat-style long jump on 2th grade male students of SMP Negeri 2 Manganitu. There is an influence of plyometric training on the ability to squat-style long jump in 2th grade male students of SMP Negeri 2 Manganitu. The research method used was an experimental method with treatment in the form of an exercise program given for eight weeks. The population was all male students of 2 th grade of SMP Negeri 2 Manganitu amounting to 20 people and a sample of 20 people, then divided into two groups each with 10 experimental groups and 10 control groups. Data collection instruments: Squat-style long jump test. The study design uses: randomized control groups pre-test and post-test design. Hypothesis testing using statistical techniques with $t$ test. The results of hypothesis analysis, obtained $t$ observation of 21.63 , while t table obtained from the degree of freedom $n-1+n 2-2$ that is $10+10-2=18$ and the level of confidence $=0.05$ is 2.10. In accordance with the test criteria accept Ho if tobservation is smaller than t table and reject $H o$ if $t$ observation is greater than $t$ table. Because $t$ observation is greater than $t$ table, the results of the analysis show reject Ho and accept Ha. Conclusion: Pliometric exercises given for eight weeks with a frequency of three times a week can improve the squat-style long jump ability in male students of 2 th grade SMP Negeri 2 Manganitu.
\end{abstract}

Keywords

plyometrics longjump, squat

style

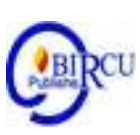

\section{Introduction}

Sport is a form of physical activity carried out by humans. As a physical activity, sport has an important role in human life, so that until now sport cannot be separated from human life and even sport is a human need. The physical ability of humans in doing work is clear evidence of how important the influence of sports in human life.

The development of sports at this time is not only carried out by certain circles, but it is well known that sports today have permeated the broad life and made a positive contribution to forming a healthy human and physical body. With the term sport is a systematic physical activity aimed at achieving achievement and health of the body, so that exercise when occupied will have a positive impact on the body. The sport of martial arts is currently in great demand by the world community, because martial arts is a legacy Indonesia's ancestral culture that deserves to be preserved, martial arts is a tactical martial, practically fast strong and can kill. (Putera, 2019)

Therefore, to improve one's physical ability in carrying out an activity, it requires a concrete effort or action. So by exercising all of that can be realized through an exercise exercises that are arranged properly. 
Someone doing training is a form of effort to achieve a goal. The purpose of the training is to obtain the maximum possible achievements, but in the implementation process, the training is not easy and simple. The training program provided by the trainer is very important in supporting the quality of training in accordance with the physical abilities of the athlete being trained. So training plays an important role in supporting athlete achievement.

The existence of a trainer in the effort to develop an athlete's achievement is needed, because the trainer knows the extent of the potential athlete he is training and knows ways to develop the athlete's potential. Providing training and having a proper training program from a coach will further enhance the athlete's ability to achieve maximum performance. This shows how important the role of the coach in supporting the achievements of an athlete.

The branches of athletic sports, especially squat-style long jump, physical ability and mastery of the basic long-jump squat style greatly affect the ability of an athlete to do a long jump squat style. Most athletes and coaches only pay attention to and develop basic technical skills in squat-style long jump without paying attention to their physical abilities so they fail to achieve maximum performance.

Coaching and providing proper training are important factors that affect the ability of a long jump athlete to jump. But in reality in schools the teachers do not yet understand how to train and improve their jumping skills in the long jump. In doing training, it is also important to note by a trainer whether the athlete's physical condition is able to accept the training load that will be given.

In addition, one important aspect in developing athletes' achievement is adequate sports facilities and infrastructure. Coaching and providing appropriate training and supported by the availability of adequate sports facilities and infrastructure will increasingly make an athlete become more developed in achieving maximum performance. But it is unfortunate to date in schools, in addition to the factor of fostering and providing poor training, also the lack of facilities and infrastructure hinders the development of students to achieve maximum performance.

As happened in SMP Negeri 2 Manganitu, which is located in the Sangihe Islands Regency, is $\pm 25 \mathrm{Km}$ from the center of Tahuna and can be traveled by two-wheeled or fourwheeled vehicles in about one hour. With its presence which is quite far from the city center, SMP Negeri 2 Manganitu still does not have adequate sports facilities or infrastructure, not least for athletics, especially long jump.

SMP Negeri 2 Manganitu, actually already has a field even like a special jump for long jump, but the lack of attention and care from the school makes the field and long jump jump tub untreated and well maintained so that it cannot be used effectively.

In SMP Negeri 2 Manganitu many male students have the potential to be able to do long jump squat styles. But it is very unfortunate because the physical condition and understanding of the basic techniques in doing long jump squat style is still far from expectations, making the results of their jumps are not good so that injuries often occur during the jump and cause doubt - even fear in making the jump.

In addition, the sports teacher at SMP Negeri 2 Manganitu also did not understand and do the exercises correctly. Most sports teachers do exercises based solely on their experience, and are impressed by guessing models or forms of training not by following the principles or principles of training. In addition, the ability of a teacher to provide training must also be supported by a well-organized training program.

Doing the long jump squat style requires leg muscle explosive power. Explosive power is a very important component of motion in supporting explosive physical activity. Leg muscle explosive power plays an important role when jumping on the long jump squat force, 
because when the repulsion jumps to reach a height, the more dominant role is explosive movements, ie movements that require leg muscle explosive power.

It takes techniques, training systems, and forms of exercise arranged in an exercise program, aimed at developing leg muscle explosive power. One form of leg muscle explosive power training is plyometric exercises. As a form of exercise, plyometric exercises are very effective in increasing leg muscle explosive power, provided that plyometric exercises can be done as well as possible.

Therefore the ability to do long jump squat style is greatly influenced by plyometric exercises. The role of plyometrics exercises in increasing leg muscle explosive power is very large automatically it affects the athlete's ability to perform repulsions in the long jump squat style. for that plyometric exercises greatly affect the ability of athletes to do long jump squat style.

Based on the above problems, the researcher is interested in researching about: The effect of plyometric training on the ability to squat-style long jump in 2th grade male students of SMP Negeri 2 Manganitu.

\section{Review of Literatures}

\subsection{Itself Ability to Jump Style Squat Style}

Long jump is one of the jump numbers in athletics. Long jump is a form of movement to jump, float and land as far as possible. So long jump can be said as a movement to lift the body from one point to another by bending one leg and landing with both feet with good balance and attempted to land as far as possible. According to Suyono Danusayogo, the jumping distance is determined by three parameters: 1) the speed when shaking or overlapping, 2) the repulsion angle, 3) the height of the weight point when overlapping, of the three the speed of shaking and the repulsion angle are the most important.

In long jump there are three kinds of styles: 1) long jump squat style (tuck), 2) long jump style hang (hang style), 3) long jump style walking in the air (walking in the air). What distinguishes these forces is the movement of time floating in the air. All the long jump styles require good physical abilities such as strength, explosive power, agility and balance and are equipped with basic technical mastery.

The basic technique in doing long jump squat style consists of four stages: prefix, pedestal or repulsion, hovering, and landing. The four stages must be mastered and must be carried out in harmony and not intermittent in order to achieve optimal performance. For more details, the four squat-style long jump techniques can be described as follows:

\section{a. Prefix}

The prefix is the first stage in squat-style long jump. The purpose of the prefix is to get the maximum speed when going to jump and bring the jumper to the optimal position to repulse. The correct prefix is a prerequisite that must be met, to produce a long distance jump. The prefix is done by running, which is getting closer to the maximum speed but still being controlled to repulse. The speed factor of starting the prefix greatly affects the results of repulsion. Harsono added that "Speed is the ability to make similar movements in a row in the shortest possible time, or the ability to travel a distance in a fast time".

The characteristics of a prefix running in a long jump squat style are: 1) Fast, 2) Accurate and consistent, 3) Preparing the athlete to make a strong support. The ways to do the start in the long jump squat style are as follows: 1) Running square depending on ability 2) Increase the pace of the run slowly little by little 3) The waist is lowered slightly at one 
final step square - 4) At speed maximal do repulsion or support 5) Arranged Pile or repulsion is done right on the board.

\section{b. Pile or Repulsion}

A pedestal is a change in flat motion to upright or upward motion that is done quickly. The footing is carried out in a way that is, before the jumper has prepared himself to repulse as strongly as possible in the final step, so that the whole body is lifted up and floated in the air. Repulsion is done by rejecting one leg to overflow without stepping over the overlapping board to get the repulsion forward. According to Suyono Danusayogo the goals and objectives of athletes in repulsion or pedestal are as follows: 1) Ensuring that the weight notch is as high as possible when departing or pedestal, 2) Add the maximum level of vertical speed to the horizontal speed produced in the start of the run, 3) Starting at an optimal angle.

\section{c. Flying}

Drifting occurs after a jumper lays down on a pedestal beam, then with the body position leaning forward, lifted floated in the air, together with the swing of both arms forward. To get the jump away, you have to straighten the overlapping legs straight - straight and as quickly as possible. The attitude and movement of the body in the air are closely related to the speed of the prefix and repulsion strength. Because at the time of release from the board rejected, the body of the jumper is influenced by a force called "the earth's pulling force". This attraction dots at a point called the weight point. The power of repulsion greatly affects the ability of athletes while in the air. At that time the athlete's ability to reach maximum strength. Bompa added that "Maximum strength depends on three main factors: 1) Muscle potential, 2) Use of muscle potential, and 3) Technique".

\section{d. Landed}

The landing is the last stage in a series of squat-style long jump movements. Landing with an efficient attitude and movement is a key point that must be understood by the jumper. When landing, the jumper strains the knee and moves the waist forward, so that the upper body becomes slightly erect and the arms swing forward.

Landing using two legs simultaneously starts with the tip of the foot and continues with a flat movement to avoid injury to the muscles or joints of the foot. The attitude of landing in the long jump is as follows: 1) Landing with both feet slightly closer 2) Weight under the forward 3) Knee bent with a squatting position 4) Hands forward 5) A fixed view to the front. So, to achieve the ability to jump long squat style is strongly influenced by physical conditions and the technique of jumping.

Based on the description above, it can be concluded that the long jump squat style is a form of jumping, hovering, and landing movements, namely lifting the body from one point to another with one leg and two legs landing and body posture while in the air like someone is being squat down.

\subsection{The Nature of Plyometric Exercise}

Coaching and providing proper training are important factors that affect the ability of a long jump athlete to jump. The very basic basic training includes exercises to increase strength, speed, explosive power, flexibility, and special endurance and general endurance. Plyometrics is a training method for developing explosive power, which is an important component in the achievements of some athletes. Plyometric exercises show the full strength characteristics of muscle contractions with a very fast response so that during working muscles there is no time to relax. 
Plyometrics is the right exercise for people who are conditioned and are devoted to being athletes in improving and developing leaps, jumps, speed and maximum strength and increasing anaerobic power. According to Junusul Hairy "anaerobic power is energy that can be produced or work that can be done at maximum speed without any significant assistance from the production of aerobic energy". This plyometric training program must be carried out based on the principles of plyometric training as follows:

\section{a. Intensity}

Needs to exercise the muscles should be given objectively. The muscle parts that are to be stressed will be given more weight. During the emphasis given to the muscle part, the physiological adaptation process will apply to produce an appropriate response and produce an effect on the muscle. Weight or lightness of exercise intensity is based on the needs of the muscles being trained.

\section{b. Deuteronomy}

Replications in plyometric exercises are performed based on the athlete's condition. The test will only be applied to athletes in accordance with the training program that has been prepared based on the ability level of the athlete being trained. The level of repetition is done following the situation at the time of training. This means that the test is performed depending on the level of physical ability of athletes in doing the exercise.

\section{c. Frequency}

The frequency of exercise is based on the number of sessions in a day, weekly and monthly. The more frequent activities carried out will give more impression. Exercise that is too often will cause boredom. It also is dependent on high or low intensity stages. If the intensity is high, the frequency needs to be reduced so as not to cause muscle injury.

\section{d. Progress}

The exercise program that is to be implemented must be good for increasing fitness, muscle strength, and increasing the ability of athletes.

\section{e. Specialization}

Specialization must be attained to the objective needs to be achieved. Failure to design this specialization will result in failure in achieving objective training objectives. For the guidance of the strength of the jump, specificity should be given to the limb muscles.

\section{f. Variation}

A variety of exercises need to be made as creatively as possible according to the training program that has been prepared. Here variations in training activities are needed. So that there is no boredom.

\section{g. Overweight}

This overload gives the impression that it is carried out at levels exceeding the individual's normal ability stage. Overload in plyometrics is a combination of muscle strength and muscle endurance.

\section{h. Safety} exercises.

Safety is a matter that must be considered in doing an exercise, not least in plyometric 
Each of the principles of plyometric training, aims to increase muscle power, in order to produce athletes who excel through training that has been given. Speaking of training, Harsono added that: "the main goals and objectives of training or training are to help athletes improve their skills and achievements to the maximum extent possible".

Plyometrics exercises will be effective if the trainer can arrange the right exercise program. Here the trainer needs to guide the frequency, volume, intensity, and development, because only by practicing will a person reach a maximum level of movement skills and achieve maximum achievement. Rusli Luthan added that "There is no other way to master a skill except by practicing. Through practice, skills can be mastered and ultimately adhered to advanced ".

Based on the description above, it can be said that plyometric exercises are exercises that are carried out to increase muscle explosive power, meaning that plyometric exercises are suitable for explosive movements.

\subsection{Research Hypothesis}

The hypothesis in this study can be formulated as follows: There is the Effect of Pliometric Exercise on the Ability to Squat in Long Jump in Class Men of Class II Middle School 2 Manganitu.

\section{Research Methods}

The method used in this research is the experimental method. The operational objective in this study is to find out how much influence the plyometric training has on the ability to squat-style long jump on second-grade male students of SMP Negeri 2 Manganitu. The variables in this study are: (1) The independent variable (X), namely: plyometric exercises. (2) Dependent variable (Y), namely: Ability to squat-style long jump.

\subsection{Definition of Variable Operations}

1. Plyometrics Training is a form of exercise given to students to increase muscle power in accordance with a training program that has been prepared. The training program is carried out by jumping through obstacles, jumping stairs, rope skiping, with training for eight weeks with the frequency of training three times a week. The measurement results are the best scores achieved from three times the opportunity to jump on the long jump.

2. Squat Long Jump Ability is a score taken by looking at the distance of the jump made by the child trying three times, measured using a meter. Data obtained at an interval scale.

\subsection{Research Design}

The design used in this research is to refer to the "Randomized Control Groups Pre-Test and Post-Test Desing" design.

\begin{tabular}{|c|c|c|c|c|}
\hline \multirow{4}{*}{$\mathrm{R}$} & $\begin{array}{c}\text { Experiment } \\
\text { Group }\end{array}$ & $\begin{array}{c}\text { Pre- } \\
\text { Test }\end{array}$ & $\begin{array}{l}\text { Treatmen } \\
\mathrm{t}\end{array}$ & $\begin{array}{c}\text { Post- } \\
\text { Test }\end{array}$ \\
\cline { 2 - 5 } & $\mathrm{A}$ & $\mathrm{Y}_{1}$ & $\mathrm{X}$ & $\mathrm{Y}_{2}$ \\
\cline { 2 - 5 } & $\mathrm{B}$ & $\mathrm{Y}_{1}$ & - & $\mathrm{Y}_{2}$ \\
\hline
\end{tabular}

Information:

R: Random

A: Experiment Group

B: Control Group

$\mathrm{X}$ : Treatment 
Y1: Initial Test

Y2: Final Test

\subsection{Data Analysis Techniques}

To test data from the results of the initial test and the final test above that is analyzed using the $t$ test. Before the $t$ test is preceded by a test. The analysis requirements are: Normality Test and Homogeneity Test.

\section{Discussion}

\subsection{Presentation of Data}

Table 1. Measurement Result Data of Long Jump Ability in Squat Style of Second Class Putera Students of Manganitu 2 Middle School Before and After Training Treatment group

\begin{tabular}{|c|c|c|c|}
\hline No & Pre - Test & Post - Test & Difference Value \\
\hline 1 & 3,02 & 3,5 & 0,48 \\
\hline 2 & 3,23 & 3,72 & 0,49 \\
\hline 3 & 3,14 & 3,68 & 0,54 \\
\hline 4 & 4,11 & 4,57 & 0,46 \\
\hline 5 & 3.81 & 4,28 & 0,47 \\
\hline 6 & 3,76 & 4,21 & 0,45 \\
\hline 7 & 3,12 & 3,55 & 0,43 \\
\hline 8 & 3,04 & 3,54 & 0,5 \\
\hline 9 & 2,97 & 3,52 & 0,55 \\
\hline 10 & 4,24 & 4,70 & 0,46 \\
\hline
\end{tabular}

Table 2. Data from the measurement of the ability to jump long squat style male students in class II of SMP Negeri 2 Manganitu before and after training Control group

\begin{tabular}{|c|c|c|c|}
\hline No & Pre - Test & Post - Test & Nilai Beda \\
\hline 1 & 3,12 & 3,23 & 0,11 \\
\hline 2 & 3,20 & 3,25 & 0,05 \\
\hline 3 & 3,07 & 3,22 & 0,15 \\
\hline 4 & 4,03 & 4,11 & 0,08 \\
\hline 5 & 3,41 & 3,49 & 0,08 \\
\hline 6 & 3,87 & 4,01 & 0,14 \\
\hline 7 & 2,98 & 3,10 & 0,12 \\
\hline 8 & 3,11 & 3,18 & 0,07 \\
\hline 9 & 4,12 & 4,14 & 0,02 \\
\hline 10 & 3,49 & 3,63 & 0,14 \\
\hline
\end{tabular}

Table 3. Difference between treatment and control groups

\begin{tabular}{|c|c|c|}
\hline No & Treatment group $\left(\mathrm{X}_{1}\right)$ & Control group $\left(\mathrm{X}_{2}\right)$ \\
\hline 1 & 0,48 & 0,11 \\
\hline 2 & 0,49 & 0,05 \\
\hline 3 & 0,54 & 0,15 \\
\hline 4 & 0,46 & 0,08 \\
\hline 5 & 0,47 & 0,08 \\
\hline 6 & 0,45 & 0,14 \\
\hline
\end{tabular}




\begin{tabular}{|c|c|c|}
\hline 7 & 0,43 & 0,12 \\
\hline 8 & 0,50 & 0,07 \\
\hline 9 & 0,55 & 0,02 \\
\hline 10 & 0,46 & 0,14 \\
\hline
\end{tabular}

Table 4. Magnitude Statistics treatment group and control group.

\begin{tabular}{|c|c|}
\hline Treatment group $\left(\mathrm{X}_{1}\right)$ & Control group $\left(\mathrm{X}_{2}\right)$ \\
\hline $\mathrm{N}=10$ & $\mathrm{~N}=10$ \\
$\Sigma \mathrm{X}_{1}=4,83$ & $\Sigma \mathrm{X}_{2}=0,96$ \\
$\mathrm{Sd}_{1}=0,038$ & $\mathrm{Sd}_{2}=0,05$ \\
$\mathrm{Sd}_{1}^{2}=0,0014$ & $\mathrm{Sd}_{2}^{2}=0,0025$ \\
$\bar{X}_{1}=0,483$ & $\bar{X}_{2}=0,096$ \\
\hline
\end{tabular}

\subsection{Data Processing}

\section{a. Testing Normality of Experimental Group Pre-Test Data}

To test whether the sample is normally distributed, testing is done with the Lilliefors Test. From the calculation results, the highest difference value is Lo $=0.1255$. With $n=10$ and significant level $\alpha=0.05$, obtained $\mathrm{L}$ tab $=0.2580$. So Lo $<\mathrm{L}$ tab. Thereby accepting Ho so that it can be concluded that the sample data of the long jump ability squat style comes from populations that are normally distributed.

\section{b. Homogeneity Testing}

From the calculations, the $\mathrm{F}$ observation is 1.78. Based on the critical table the distribution of $\mathrm{F}$ at $\alpha=0.05$, with the denominator $\mathrm{dk} 9$ and numerator 9 , the $\mathrm{F}$ table is equal to: 3.18. Because Fo <F tab. Means accepting Ho and rejecting $\mathrm{Ha}$, so it can be concluded that the variance of the two measurement groups (the treatment group and the control group) have the same variance (homogeneous).

\section{c. Discussion of Research Results}

Based on the results of hypothesis testing analysis obtained $t$ observation $=21.63$. While $\mathrm{t}$ table obtained with the degree of freedom $(\mathrm{dk}): \mathrm{n} 1+\mathrm{n} 2-2=18$ and $\alpha 0.05$ (Opportunity $1-1 / 2 \alpha$ ) on the Student distribution list of 2.10, where $t$ observation $>t$ table. The results show that Ho refused and accepted Ha. Thus it can be concluded that the mean value of the distinction of the long jump ability of the squat style of the treatment group is greater than the average value of the difference of the long jump ability of the squat style of the control group.

\section{Conclusion}

By looking at the results of data analysis using statistical analysis shows that the research hypothesis then the research concluded that there is an effect of plyometric training on the ability to squat-style long jump in 2th grade male students of SMP Negeri 2 Manganitu.

Through this research it is recommended: (1) To improve the ability to jump long squat style required an exercise program that is well structured to improve the ability of leg muscles. (2) Conduct further research related to this problem by involving other factors that also influence it. (3). Become input material in the process of training and learning, especially especially in the athletics sports long jump number. 


\section{References}

Adisasmita Yusuf. (2007). Olahraga Pilihan Atletik, Departemen Pendidikan Dan Kebudayaan Direktorat Jenderal Pendidikan Tinggi Proyek Pembinaan Tenaga Kependidikan, Jakarta.

Bahagia Yoyo. (2008). Pembelajaran Atletik, Departemen Pendidikan Nasional Direktorat Jendral Pendidikan Dasar Dan Menengah, Jakarta.

Bompa O. Tudor. (2009). Terjemahan BE Rahantoknam. Periodization Theory and Methodology Of Training, UNJ Jakarta.

Danusayogo Suyono. (2007). Lari, Lompat, Lempar. Pendidikan Pelatihan \& Sistem Sertifikasi IAAF Jakarta.

Donald Arry. (1982). Lucy Chesar Jacobs and Rasavich Asyhar, Pengantar Penelitian Dalam Pendidikan. Terjemahan Arief Furman, Usaha Nasional, Surabaya.

Hairy Junusul. (1989) Fisiologi Olahraga, Proyek Pengembangan Lembaga Pendidikan Tenaga Kependidikan, Jakarta.

Harsono. (1988). Coaching Dan Aspek-Aspek Psikoligis Dalam Coaching. Depdikbud. Dirjend DIKTI P2LPTK. Jakarta.

Kardjono. (2008). Pembinaan Kondisi Fisik, Universitas Pendidikan Indonesia, Bandung.

Luthan Rusli. (2004). Perencanaan Dan Strategi Pembelajaran Penjaskes, Depdiknas, Jakarta.

Putera, S., et al. (2019). Effect of Plyometric Hurdle Hops and Tuck Jump Training on Strength and Leg Muscle Power in Martial Arts Athletes at Kostrad Company-C Malang. Budapest International Research and Critics in Linguistics and Education (BirLE) Journal. P. 566-574.

Sajoto Mochamad. (1995). Peningkatan Dan Pembinaan Kekuatan Kondisi Fisik Dalam Olahraga, Semarang: Dahara Preze.

Sudjana. (1986) Metode Statistik, Traesito, Bandung.

http://gsport-gsport.blogspot.com/2011/06/latihan-pliometrik-bahagian-1.html

http://erfahza.blogspot.com/2013/06/artikel-lompat-jauh.html 